\title{
U.S.-Russian Cooperation in Science and Technology: A Case Study of the TOPAZ Space-Based Nuclear Reactor International Program
}

\author{
Richard Dabrowski *
}

The TOPAZ International Program (TIP) was the final name given to a series of projects to purchase for testing in the United States the TOPAZ-II, a space-based nuclear reactor of a type that had been more fully developed in the Soviet Union than in the United States. The TOPAZ-II represented the more than twenty years of the Soviet space program's experience with nuclear thermionic power system technology, which matured during the period from 1969 to 1990 . In the changing political situation associated with the dissolution of the Soviet Union, it became possible for the United States to not just purchase the system, but also to employ Russian scientists, engineers, and testing facilities to verify its reliability. The TIP presented the only opportunity for Russian scientists and engineers to continue the development of thermionic space nuclear power systems for civil (non-defense) applications, as funding for these efforts in the USSR had been cut off. The TIP became the first prominent example of international cooperation between Russia and the United States in a formerly highly classified area of technology following the collapse of the Soviet Union.

The TIP story began in January 1989, when Russian scientists led by Academician Dr. Nikolay N. Ponomarev-Stepnoy of the Kurchatov Institute first described the TOPAZ-II reactor at a scientific symposium in Albuquerque. Several U.S. engineers recognized the commercial potential of this technology and succeeded in obtaining funding from the Strategic Defense Initiative Organization (SDIO) to arrange for delivery and testing in Albuquerque of six functioning models, eventually employing up to fifty Russian scientists, engineers, and technicians at any one time and over 250 Russians total from 1991-95 to work with U.S., British, and French scientists and engineers on proving its effectiveness.

They began working together as the Thermionic System Evaluation Test (TSET), conducting thermal vacuum, electric power, and mechanical testing and evaluation of the USSR-built TOPAZ-II without nuclear fuel. The successes of TSET led to the ambi-

\footnotetext{
Richard Dabrowski is a Lieutenant Colonel in the United States Air Force. He holds a doctorate in instructional systems technology from Indiana University, and is currently a faculty member at the George C. Marshall European Center for Security Studies. The publication of the information contained herein does not constitute endorsement by the United States Department of Defense, or any other U.S. government agency, of any activity of the publishing organization, or other organizations referenced or published by them, or the information, products or services they provide. The United States Department of Defense does not exercise any editorial control over the information provided by these entities. The views expressed in this article are those of the author and do not reflect the official policy or position of the George C. Marshall European Center for Security Studies, the Department of Defense, or the U.S. Government.
} 
tious Nuclear Electric Propulsion Space Test Program (NEPSTP), which proposed placing a TOPAZ-II reactor in space; however, NEPSTP was cancelled before this was attempted. Meanwhile, ancillary testing regimens, such as the Thermionic Fuel Element Verification Program (TFEVP), provided valuable insights into the durability of components and materials science in general as well as ways to ensure the nuclear safety of the space reactor. For complex political and technical reasons, funding for TIP was cut in 1996, forcing the return of the scientists and the functioning TOPAZ models to Russia. The lessons learned from the TIP illuminate some of the institutional and cultural challenges to U.S.-Russian cooperation in technology research that remain true today.

\section{The Science of TOPAZ}

"TOPAZ" is a Russian acronym for "Thermionic Experiment with Conversion in Active Zone." The TOPAZ power system utilized thermionic energy conversion, a process in which a heated surface emits electrons that are collected by a cooler surface. This transfer of electrons generates electrical power. This process is completely static, meaning that there are few moving parts, making the reactor highly durable and reliable.

There were two types of TOPAZ reactors: the TOPAZ reactor developed by the Krasnaya Zvezda (Red Star) Scientific Industrial Association and the Institute for Physics and Power Engineering, and the TOPAZ-II reactor developed by the Kurchatov Institute of Atomic Energy, the Central Design Bureau for Machine Building, and the Research Institute of the LUCH Scientific Industrial Association. The TOPAZ-II reactor featured a single-cell construction of the Thermionic Fuel Elements (TFEs), while the TOPAZ used a multi-cell construction. The single-cell TFEs in the TOPAZ-II allowed for a non-nuclear testing process in which tungsten electric heaters could be substituted for nuclear fuel, which reduced the financial costs and improved the safety and environmental considerations of determining power system performance and reliability characteristics.

What made the thermionic fuel elements in a TOPAZ-II reactor work efficiently was the manufacture of single crystal, refractory metals, and insulating ceramics in large amounts, all capable of withstanding severe radiation and plasma environments. This materials science research and development at the Soviet Scientific Industrial Association "LUCH" in Podolsk under Dr. Yuri Nikolaev was extensive and generally more advanced during the 1970s and 1980s than comparable efforts at Western institutions. The combination of innovative design and unique materials made the TOPAZ-II reactor highly desirable for powering space-based sensor platforms.

\section{Historical Context}

Thermionics have the potential to supply more electrical power to satellites than could be provided by solar arrays and to operate in more hostile environments. However, developing thermionic energy conversion devices has proven difficult. The United States made progress in thermionic technology during the 1960s, but momentum waned in the early 1970 s due to a shift in space technology funding priorities. Meanwhile, the Soviet 
Union invested substantial resources to establish research institutes, testing facilities, and manufacturing plants dedicated to the development of thermionic reactors. ${ }^{1}$

The advent of the Strategic Defense Initiative (SDI) in the early 1980s rekindled interest and investment in thermionics to power a space-based ballistic missile defense system led by the United States Air Force. In 1981, Joseph Wetch brought together research colleagues from the 1950s and 1960s-era "Systems for Nuclear Auxiliary Power" (SNAP) program into a new company named Space Power Incorporated (SPI). Their first contract with the U.S. Air Force was to survey technology worldwide that might advance U.S. capabilities in space nuclear power. SPI reviewed thermionic research in France, the Netherlands, Sweden, Germany, and the Soviet Union. Of these countries, only the Soviet Union had conducted power tests of the TOPAZ thermionic reactor-converter in the early 1970 s. $^{2}$

Soon thereafter, SPI landed a NASA-managed contract to determine the feasibility and conceptual design of space nuclear power systems for ballistic missile defense. While this development work was going on during 1987-88, the Soviets launched two new thermionic reactors, which operated in space for several months. The launches prompted a meeting between the USAF and its contractors in late 1988, during which ideas were solicited for a smaller and quicker reactor system development than the Space Power 100 project. Joe Wetch jokingly suggested buying one of the new Soviet reactors that had just debuted in orbit, an idea that was taken seriously by Richard (Dick) Verga of the Department of Defense's Strategic Defense Initiative Organization (SDIO).

Mr. Verga was dissatisfied with the technical progress being made on the Department of Energy-managed Space Power 100 program, which was the closest comparable U.S. effort at that time. The dollars and time required to complete the program were both growing. In addition, the test facility for a full nuclear test was going to cost approximately USD 100 million. The United States needed to rethink its approach to developing space nuclear power. While it was known that the Russians had twice launched a TOPAZ reactor into space, the technical differences between the TOPAZ and TOPAZII and who had developed them were just emerging.

A few months later, in January 1989, Verga invited the key leaders of the Russian space nuclear power program to the Albuquerque Space Nuclear Power Symposium. There, Joe Wetch first met the Russian lead, Academician Nikolay Nikolayevich Ponomarev-Stepnoy of the Kurchatov Institute of Atomic Energy (KIAE), and learned that he was interested in a partnership with the United States. Also at the symposium, Dr.

1 The history of the Soviet space nuclear energy program is detailed in N. E. Kucharkin, N. N. Ponomarev-Stepnoy, and V.A. Usov, Космическая ядерная энергетика (ядерные реакторы с термоэлектрическим и термоэмиссионным преобразованием - «Ромашка» $и$ «Енисей») [Space Nuclear Power (Nuclear reactors with thermo-electric and thermionic conversion - "Romashka" and "Yenisey"), 2nd ed.] (Moscow: IzdAt, 2012), 12-136.

2 The history of the U.S. space nuclear energy program is detailed in National Research Council Staff, Thermionics Quo Vadis? An Assessment of the DTRA's Advanced Thermionics Research and Development Program (Washington, D.C.: National Academies Press, 2001), 26-32. 
Georgi M. Gryaznov, director of the Krasnaya Zvezda Scientific Industrial Association, gave a formal presentation describing the design of the new "TOPAZ" reactors, which had just completed their two initial flight demonstrations. The Krasnaya Zvezda's multicell design was very similar to the General Atomics' multi-cell fuel elements that were under development in the United States. Early the next morning, Academician Ponomarev-Stepnoy suggested to Joe Wetch that the United States purchase the Russian reactor. Wetch and his partner from SPI, Dr. Ned Britt, invited the Russian delegation to a dinner and while there came to an agreement in principle to do exactly that, provided the arrangement was approved by the Soviet Union and the United States.

\section{Getting Started}

What followed was a series of meetings and site visits in Russia to come to an agreement about this potential purchase. During their first meeting in Moscow at the KIAE, Wetch and Britt received a briefing on a heterogeneous zirconium hydride moderated thermionic reactor, with the entire thermionic fuel element (TFE) as one long single cell. It was simpler to fabricate a single-cell fuel element than a multi-cell fuel element; a single-cell TFE was more reliable and maintained reasonably good efficiency and performance over its lifetime. Wetch and Britt named it "TOPAZ-II" to distinguish it from the multi-cell TOPAZ that had been assembled at Krasnaya Zvezda Scientific Industrial Association and which had already been flown in space; later they learned that the Russians called the single-cell reactor the "Yenisey" after the Yenisey River in Siberia. The Russians also informed them that they had built several of the TOPAZ-II systems and had a plan and facility for testing the reactor without going critical and generating any radioactivity. However, they would not release more information until together they had formed a joint venture and submitted a test and financial plan to the Ministry of Atomic Energy (Minatom) to obtain approval for working with the United States.

Joe Wetch and Ned Britt formed a new company called International Scientific Products (ISP), which could legally communicate on an unclassified basis with the Russian scientists. During several more visits and tours over the course of 1989, they agreed to establish a joint venture between ISP, KIAE, and the other organizations involved in creating and testing the TOPAZ-II: the Scientific Industrial Association "LUCH" in Podolsk (represented by Deputy Director Yuri Nikolaev), the Central Design Bureau for Machine Building in St. Petersburg (represented by its Director Vladimir Nikitin), and the Keldysh Institute of Rocket Research in Moscow (represented by its Director Academician Anatoli Koreteev). The joint venture was named "International Nuclear Energy Research and Technology" - or INERTEK-with Academician Ponomarev-Stepnoy as the president and Joe Wetch as his first deputy. Each company/institute signed the protocol, and it was submitted to the Ministry of Atomic Energy, finally becoming official in December 1990.

Upon returning to the United States after each trip, Wetch and Britt informed Dick Verga of their progress. Verga kept his management briefed, and the SDIO agreed to negotiate for the purchase or lease of the Topaz-II, but performance verification tests had to be done in the United States. It was mostly Verga who finally persuaded Minatom 
that the full reactor tests had to be conducted in the United States with a joint RussianU.S. technical team if the United States were to join in flight testing and future commercial applications. Minatom agreed after including a provision that the TOPAZ-II reactors had to be returned after the tests and that they should not be used for military purposes. Verga also convinced the United Kingdom and France to assign researchers to the project, mostly as a cost-savings measure, though their participation did make the TOPAZ project truly international. The United States Air Force contracted with ISP, who in turn contracted with INERTEK for the purchase, packaging, transport, reassembly, installation, testing, and final repackaging and return of the TOPAZ-II reactors together with vacuum and other test equipment. This initial international cooperative project was called the Thermionic System Evaluation Test (TSET).

\section{TOPAZ-II Delivery to the U.S.}

To satisfy both the TSET and NEPSTP projects, there were two purchases and shipments to Albuquerque of TOPAZ reactors and associated technology. The first of the shipments was for TSET, and involved the purchase of two TOPAZ-II reactors and all associated test equipment as well as the required Russian technical support to reassemble everything and conduct testing. The second shipment in 1994 of four (unfueled) reactors was for NEPSTP, two of which were capable of being space flight qualified. One of these flight capable units was expected to be launched into orbit as the power source for a prototype spacecraft was being designed by the Johns Hopkins University Applied Physics Laboratory.

First Shipment. In late April 1992, a team from the United States (led by Army Major Fred Tarantino of SDIO) traveled to Russia to complete the TOPAZ-II purchase, take delivery of the hardware, prepare the hardware for shipment, and ensure delivery to the United States. United States Air Force Major Dan Mulder was in charge of the logistics - seeing that all the equipment, some eighty-five large crates, and two TOPAZ reactors in shipping containers - were hauled by truck to the Polkova I airport. There were three issues: identifying crates that contained hazardous material so they could be properly marked; ensuring that a crane was available to lift crates onto the pallets that fit into the American military cargo planes; and securing a large enough area at the airport to store the crates until the cargo planes arrived. Major Mulder was able to get all of the crates moved to the airport over the next two days and had a crane waiting in place to load the aircraft pallets. The rest of the operation was far from simple.

A United States Air Force Airlift Control Element Team (ALCE Team) had been arranged to ensure that the cargo was properly prepared for transport. On 26 April 1992, a C-141 and a C-130 brought in the ALCE Team and all their loading equipment. All seemed to go well, until it came to loading the extremely delicate tungsten heaters. Although these units were packed in special cases, there was great concern about vibration and jostling during flight. They could not find any packing material that would effectively cushion the cases containing the heaters. Finally, Britt had the Russian technicians go to furniture stores in St. Petersburg and buy foam sheets. The heater cases were nes- 
tled between stacks of foam sheets and strapped down on top of the crates - an approach that must have worked, because the heaters arrived intact.

Unfortunately, a significant difficulty then arose with the issue of the export license for all the TOPAZ equipment. The official in charge of the customs office at the St. Petersburg airport would not recognize the existing export license, as it had been approved by the Soviet Union, which had ceased to exist, and had been supplanted by Russian Federation. Without an export license, Major Tarantino could not provide the U.S. Air Force with a firm date and time for pickup. In addition, since May Day celebrations were approaching, there was no one available in Latvia or Estonia to arrange country overflight clearance for the aircraft. They had the equipment at the airport, but an invalid export license and no airlift.

The sale/export still needed approval from the customs office. Late in the evening of 27 April 1992, Academician Ponomarev-Stepnoy and the Director of INTERTEK, Benjamin Usov, were able to arrange a meeting in Moscow with the Chairman of the Government of the Russian Federation, Alexander Shokhin, and reported to him about the critical situation involving the shipment. Shokhin consulted with the Minister of Foreign Economic Relations, Sergei Glazev, and a decision was made to immediately issue a one-time export license. The following morning, a new export license was signed and clearance for shipment was approved for 1 May. A charter flight was quickly arranged to get the export license to St. Petersburg.

However, it took another five days to get the required overflight clearance for Latvia and Estonia because of the approaching weekend, two days of Baltic holidays, and no established after-hours diplomatic procedures for obtaining overflight clearance. They still needed two C-5 aircraft to pick up the loaded pallets; while these planes were on the way to Russia, one had broken down in England. The other C-5 landed in St. Petersburg on 6 May 1992. The two TOPAZ reactors and as much equipment as possible were loaded on this C-5 and it departed the same day. The second C-5 arrived on 8 May and was loaded with the remaining equipment and departed. Unfortunately, the second C-5 experienced another maintenance problem during a layover in England. After another two days of delay the second C-5 finally arrived at Kirtland AFB in New Mexico on 12 May, five days after the arrival of the first aircraft.

Second Shipment. For the second shipment in 1994, it was decided to charter a commercial transport aircraft rather than use military planes. ISP arranged a charter flight with Russian Volga Dnepr Airlines for an Antonov-124. The An-124 was the world's largest cargo aircraft, and this plane was able to haul all four of the TOPAZ reactors in their shipping containers. There were a few administrative problems, but none so difficult as had occurred with the first shipment.

\section{Testing in Albuquerque}

In April 1990, Dr. Mike Schuller and Major Dan Mulder met with Dick Verga of SDIO while attending the Space Power Workshop at the United States Air Force Space Division. Verga introduced them to the possible purchase of a Russian TOPAZ reactor. Would the Air Force Weapons Lab be interested in testing it for SDIO? Both said they 
would be very interested in testing the reactor if SDIO purchased it. They didn't have a test team, a building to test in, or for that matter anyone who had managed a large hardware project. Later they found Frank Thome of Sandia National Laboratories, who did have experience managing large hardware programs, and in December 1990 he was hired to manage the Thermionic System Evaluation Test (TSET).

The U.S. Air Force Phillips Laboratory felt it would be advantageous both technically and politically to include Los Alamos, Sandia, and the University of New Mexico in the program. They formed the New Mexico Strategic Alliance for Thermionic Space Nuclear Power. This alliance ensured political support from U.S. Senator Pete Domenici (a Republican from New Mexico), access to additional government scientists from Sandia and Los Alamos during the course of the program, technicians with the required skills to conduct system level tests in vacuum, and over USD 500,000 worth of excess equipment from the salvage yards of Sandia and Los Alamos.

The decision was made to place TSET at the University of New Mexico (UNM) for its availability and large test space in an unclassified environment. The transparency of the location was important to the Russians, as it allowed them to highlight the peaceful nature of the research program. In addition, having UNM as sponsor gave management considerable organizational flexibility. Contract manager Tim Stepetic reported, "The University was very cooperative and accommodating. ... UNM allowed me to open checking accounts to provide responsive payments for the support requirements of the INTERTEK and LUCH contracts - I don't think they've ever permitted such checkbook arrangements either before or since...." Approximately USD 400,000 to cover all Russian per diem, local travel, and other associated expenses were run through these checking accounts. When this unorthodox situation came to the attention of others through a routine audit, it provoked a General Accounting Office (GAO) investigation into this and other management practices, though no significant irregularities were found. ${ }^{3}$

\section{Test Facility}

In April 1991, the USAF signed a contract to lease a building belonging to the New Mexico Engineering Research Institute (NMERI), part of the University of New Mexico. However, an empty building was a long way from a finished test facility and trained people. Frank Thome and his team put together modification specifications for the building, reviewed drawings, set up Russian language training, vacuum and liquid metal training courses, developed a program plan, and worked long hours to prepare the facility. TSET training manager Scott Wold supervised the required structural changes and equipment installation. By the time the Russian TOPAZ team arrived in April 1992 to provide training on the TOPAZ-II reactor and demonstrate how to conduct a system level test, they had the building ready.

3 Rachel Smolkin, "TOPAZ Nuclear Program Called Failure; GAO Report Claims Mismanagement in Tech-Transfer Effort," Rocky Mountain News (21 December 1997). 


\section{TSET}

The TOPAZ-II system, ground support equipment, and the "Baikal" thermal vacuum test stand were delivered in May 1992, together with previously documented results from manufacturing records, assembly inspection reports, system acceptance tests, modification records, repair logs, and high temperature performance evaluations. Russian and U.S. specialists worked side-by-side in the TSET laboratory to install, calibrate, and accept the technology as well as to demonstrate and verify the previous Soviet test results. The TSET experience established the baseline for development and demonstration of future thermionic space nuclear power systems. In addition, TSET successfully showed how former Cold War adversaries could work together effectively and economically; that military technology could be adapted to peaceful, non-military applications; and that Russian specialists who were previously employed for military purposes could successfully cooperate with foreign specialists.

\section{NEPSTP}

Once the safety and reliability of the TOPAZ-II system had been demonstrated on the ground, the next step was to fly a prototype in space. The Nuclear Electric Propulsion Space Test Program (NEPSTP) was an international space mission sponsored by the SDIO/Ballistic Missile Defense Organization (BMDO) as a testbed for the development of nuclear electric propulsion technologies. The mission proposed using the TOPAZ-II thermionic nuclear reactor as the power source and a variety of advanced experimental electric thrusters from international sources for propulsion. A shock-and-vibration test was done on a complete satellite that simulated launch conditions and it passed with few mechanical or electrical problems. The Johns Hopkins University Applied Physics Laboratory designed a prototype spacecraft and testing program, although the spacecraft was never developed beyond the design phase, as BMDO cancelled NEPSTP in 1993. ${ }^{4}$

While NEPSTP was ultimately cancelled due to budget and anti-nuclear political pressures, the testing program in Albuquerque showed that safety concerns and cost-effectiveness could be balanced. Retired Sandia National Laboratories scientist Albert Marshall commented, "We were able to convince critics and openly hostile groups that NEPSTP could be carried out safely. I believe that the success of our approach will set a valuable standard for all future space reactor missions." Evidence for that included the (since-cancelled) 2003 "Project Prometheus," a NASA-sponsored effort to develop nuclear-powered propulsion for long-duration space missions, which included non-nuclear pre-launch testing similar to what had been learned from Russia during TSET.

\section{Ancillary Programs}

A major adjunct to TSET was the Thermionic Fuel Element Verification (TFEV) program. At the same time as negotiations were proceeding for the TOPAZ purchase, Dick Verga became interested in purchasing a TFE test rig (then located in Podolsk), as it

4 John Fleck, “TOPAZ Research Funds at Risk,” Albuquerque Journal (11 January 1996). 
might speed the development of thermionic fuel elements in the United States. Based on the past accomplishments of the Department of Energy thermionic fuel element program, the life of thermionic reactors was projected to be about one year. The TFEV program validated the potential of thermionic reactor systems to meet mission life requirements ranging from three to seven years, and there were indications that longer life might be possible. This was not the only side project: The unprecedented access to thermionic technology, testing documentation, testing facilities and equipment, and most importantly direct contact with former Soviet scientists and engineers, allowed for joint and international developments in materials science.

These other efforts included researchers from the United Kingdom and France and were conducted in Albuquerque alongside TSET and TFEV, leading to breakthroughs useful in severe radiation and plasma environments. British scientist Paul Agnew recalled, "I started to design a test facility to evaluate the influence of long-term exposure to cesium vapor on the surface electrical properties of various insulating ceramics. We began construction of the experimental facility in a corner of the bay housing the TFE rig. I was joined by Judith Ing (also from the U.K.). ... Our materials studies were very much a 'side show of the big show,' but everyone made us feel part of the team and that our work was important." Judith Ing concurred, "It was an extremely exciting and effective working environment which achieved a huge amount in a short period of time." This contribution to scientific advancement is suggested by the bibliography of the Soviet/ Russian history of space nuclear power, which lists sixty-two journal articles and scientific conference presentations worldwide related to all aspects of thermionics development. $^{5}$

\section{Lessons Learned}

All of the key Russian and U.S. personnel involved contributed to a 1995 report titled TOPAZ International Program: Lessons Learned in Technology Cooperation with Russia. ${ }^{6}$ This report divided the lessons learned into five categories:

1. U.S./Russian Perspective

2. U.S. Federal Agencies and Legislative Environment

3. Russian Institutional Partnership

4. Business and Management Differences

5. Human Relations Issues.

The lessons are summarized below and updated with insights gathered from more recent interviews, emails, and published sources.

5 Kucharkin, et al., Космическая ядерная энергетика [Space Nuclear Power], 203-11.

6 Booz, Allen \& Hamilton, TOPAZ International Program: Lessons Learned in Technology Cooperation with Russia (Springfield, VA: Stephenson Printing, 1995), 55-74. 


\section{U.S./Russian Perspective}

Neither the United States nor Russia can assume technological superiority in all areas, yet political considerations can hamper the willingness to cooperate if the exchange is seen as one-sided. The TOPAZ program showed the value of a technology partnership that gave the Russians an active role in the future of the technology they developed. As the report states, "A well thought-out partnership allows both Americans and Russians an opportunity to learn about each other's capabilities and to develop a trusting relationship."7 The TOPAZ International Program included three such opportunities:

- Joint Testing and Evaluation. Russian specialists participated in the TSET system tests and safety assessments in Albuquerque, which included the training of the U.S. facility operators to take over their roles.

- Joint Technology Demonstration. Russians worked with U.S. engineers to design reactor safety modifications for the NEPSTP proposed launch of a fueled nuclear reactor. In addition, nuclear criticality tests and post-irradiation examination of reactor components were conducted at Russian test facilities.

- Joint Development. U.S. firms teamed with Russian institutes to start advanced reactor development that was to follow NEPSTP.

From the U.S. perspective, the work done in Russia had the potential to reduce the cost and time required to develop an equivalent U.S. technology base. Another consideration is that joint thermionic technology efforts kept highly skilled Russian nuclear experts employed in Russia. Funding for their institutes also allowed Russian scientists and engineers to adopt new skills that were useful in an open-market economy so that they were better able to market products that they had created. Using funds received from the United States under these contracts, the Russian institutes were able to convert some of their defense activities into peaceful civilian ones and develop a number of new technologies such as ozone-friendly refrigerants, ceramic/metal x-ray tubes for medicine, ultra-strong mono-crystalline alloys, and other products.

\section{U.S. Federal Agencies and Legislative Environment}

The United States has enacted significant legislation and regulations restricting sales of technical components and technology to and from foreign countries. Some of these restrictions may be obsolete in an evolving political environment, yet they still exist. For international science and technology cooperation to succeed, persistence is required to work through these bureaucratic obstacles. In the early days following the collapse of the Soviet Union, advocates of Russian-U.S. scientific cooperation had to deal with Cold War-era regulations and also a residual almost paranoid mindset among some officials, both in Russia and in the United States. This was particularly evident in the drama surrounding a non-functional full-scale TOPAZ exhibit.

7 Ibid., 54. 
Before the TOPAZ reactors were purchased, a display TOPAZ unit was shown as an exhibit at the Eighth Symposium on Space Nuclear Power held in Albuquerque, New Mexico in January 1991. Once in the United States, the display unit became trapped in tangle of bureaucratic red tape that prevented it from being returned to Russia. The Nuclear Regulatory Commission (NRC) determined that it was illegal to export a "nuclear utilization facility," as they had classified the display reactor. Even though it was a nonfunctioning exhibit, the NRC claimed it might be possible to modify and convert it into a functioning unit, and therefore it could not be returned to Russia. It took five months of wrangling and pressure from both sides, including the intervention of New Mexico Senator Pete Domenici, to define the TOPAZ exhibit as not a "nuclear utilization facility" so it could be sent home. ${ }^{8}$

In view of the problems with the TOPAZ display unit and other issues related to a license needed to import a nuclear system, it was decided to bring the unfueled reactors into the United States as property of the U.S. government. This created a complication, because the reactors were to be purchased from INERTEK (a Russian joint venture company) by International Scientific Products (a private U.S. corporation). It was intended that ISP would then resell the reactors to the U.S. government. A solution was found: after the first reactors and all of the crates with the test equipment had been loaded onto a C-5 cargo plane, a signing ceremony was held inside before it took off. As the vice president of ISP, Ned Britt signed the contract to purchase the hardware from INERTEK and immediately signed another set of papers to resell the same items to the U.S. government. In this way, by the time the planes landed in Albuquerque, all of the cargo was already government property and exempt from most of the challenges to importing nuclear hardware.

Such bureaucratic obstacles existed on multiple levels. As an example, TSET training manager Scott Wold described that on more than one occasion the TOPAZ team would be notified by some outside organization that after careful consideration, "they had concluded that an experiment we proposed to do wouldn't be possible and that we should just stop all work on the project as it was obviously a waste of time. Our typical response would be to provide them with the results of the experiment we had just wrapped up." Wold credited Thome and Mulder for the success of the TOPAZ program, as they provided the "top cover" needed to be able to focus on the tasks at hand without getting involved in the politics associated with the program.

\section{Russian Institutional Partnership}

In order to strengthen the partnership, the U.S. and Russian team members needed to become acquainted with each other. The primary lesson learned was that building a close relationship between Russians and Americans could allow for communication exchanges that would otherwise not take place. This was not an issue of language barriers, as those working together on the TOPAZ program were able to get by using a few key

8 R. Jeffrey Smith, “U.S. Won't Let Soviets Take Reactor Back Home; Conference Exhibit Trapped in Legal Limbo," Washington Post (20 April 1991). 
words in each other's language and numerous drawings and sketches, supplemented when necessary by staff technical interpreters. Rather this was an issue of willingness to take the extra steps necessary to resolve a difficult situation such as that which occurred with the export license for the initial TOPAZ shipment. This willingness resulted from the friendships that were formed during site visits, attendance at academic and technical exchanges, and especially social interactions.

While the Russian and U.S. participants have many fond memories of time spent together, two occasions stood out: a visit to the Trinity Test Site at White Sands, New Mexico, and riding in a hot air balloon. There were fourteen Russian engineers and technicians who arrived on 3 April 1992 to begin a joint Russian-U.S. training program to acquaint everyone with the TOPAZ equipment and testing protocols. The arrival date was chosen because 4 April was one of only two days per year that the Trinity Test Site (where the first atomic bomb exploded) was open to the public. This was seen as a unique opportunity for a cultural excursion that would particularly appeal to those working in nuclear science. Despite getting only three hours of sleep after a transatlantic flight, the Russians were awoken at $5 \mathrm{AM}$ to be loaded into vans together with their American hosts and families for the trip. Georgiy Kompaniets recalled, "It was like for a picnic! And at the entrance to the site there were souvenir vendors selling t-shirts with bombs and rocks supposedly from the epicenter of the blast...." The Russians quickly became the center of attention for the media and were interviewed for television. They were able to tour the McDonald ranch house, which was where the first atomic bomb was assembled and from where it was detonated. It was all "simply a wonder."

Another cultural excursion that made an indelible impression was the chance to ride in a hot air balloon. A hot air balloon club based in Albuquerque offered free rides to the Russian guests, who had become minor local celebrities - an offer that was eagerly accepted, as no member of the group had ever had such an opportunity. Boris Steppenov recalled, "The greatest difficulty, it seemed, was landing. And it was absolutely forbidden to touch down on reservations belonging to Native Americans, as this would be seen as an attack on their land and an affront to their ancestors." Yet winds cannot be controlled, and this is exactly what happened to the balloon in which he was riding; the tribal police were notified, and they came and gave the balloon pilot a ticket for the transgression. Steppenov was then able to rejoin the other first-time riders in a ceremony to celebrate the occasion. "There were speeches, there were oaths, there was baptism with champagne and many other rituals. A memory for an entire life!"

\section{Business and Management Differences}

The arrival of the TOPAZ scientists and technicians was likely a much greater culture shock for the Russians than for the Americans. As Valery Sinkevych, lead engineer, noted: "It was incredible that several hundred Russians, who had worked their entire adult life under the strictest security, could suddenly plunge into another world altogether." This was evident on the first work day in Albuquerque, when Ned Britt explained to Sinkevych that he should start by opening boxes, arranging equipment, etc. Sinkevych replied that before he could do that, as was customary he needed authoriza- 
tion from his director. Britt immediately placed a call to Russia to Central Design Bureau of Heavy Machine Building Director Vladimir Nikitin and asked that Sinkevych as INTERTEK representative in Albuquerque be delegated the responsibility for such decisions. Nikitin agreed and from then forward there was a reasonable allocation of powers between those in Russia and those in the U.S., which contributed to a quick resolution of technical issues.

Sinkevych worked with Glen Schmidt and Scott Wold on the daily tasks of setting up the equipment and running the tests. Schmidt held a standup meeting each morning before testing and assembly began to make sure all personnel were present, knew their assignments for the day, and had the resources they needed for that day. During the day, Sinkevych and Schmidt would walk around the work areas and observe, inquire, and/or assist each person, as needed. At the end of the day, a standup meeting was held to review progress, problems, and identify actions to be taken during the night or next day. The Russian engineers and technicians called Schmidt "the walking stick," and Schmidt told them that was his management style: "Management by Walking Around."

The estimated time required for installation and test was more than nine months from start to completion of the TOPAZ-II test systems and successful demonstration of an operational thermal cycle of the power system. The actual elapsed time was six and a half months from start to completion of the acceptance test. Sinkevych explained, "The trust that was formed between the Russian and the American side allowed us in an unusually short time to complete the assembly of the complex and demonstrate its capabilities." The shortened time from start to successful completion of the thermal-vacuum test saved a lot of money for the fixed price ISP/SPI effort and gained future programmatic respect.

Because time and money were being saved by the joint efforts of Russians and Americans, Schmidt recommended to Wetch and Britt that a bonus should be paid to each Russian to show appreciation for their unusual accomplishment. Bonuses were paid in relationship to their technical assignment, duration of performance, and quality of workmanship. This was the first time that any of the Russians had been paid a bonus. About a month after the first bonuses, several Russians asked if they would/could get another bonus if even more time was saved. Schmidt's answer to them was a qualified "perhaps." They did save more time, and they were given another, smaller bonus. In this and a myriad of other ways, the Russian personnel became acquainted with Western management practices, which benefited them personally and contributed to the success of the program.

\section{Human Relations Issues}

TSET training manager Scott Wold recorded many of the "culture shock" moments that reflected what it meant for Russians to work with Americans during this time and place. He particularly remembered:

- Taking the Russian engineers and technicians on tours of the local electrical, valve and fitting, hardware, and fastener supply companies and explaining that Americans can get almost anything we may need at any time. 
- Having the Russian engineers sitting in our training courses, only to find out that even though they worked on the project for years, they only knew what their particular component did - only a few had knowledge of how the entire system operated.

- One of the engineers was returning to Russia as his son was having an operation to remove a brain tumor, and the surgeon asked the engineer to bring back some Tylenol if possible. It was amazing that (at that time) Russia was a country capable of performing brain surgery but incapable of providing basic medicines.

The U.S. support staff in Albuquerque worked to reduce Russian culture shock and adapt more readily to living in the United States. They did this by having the Russians live in the same housing complex so that they could support each other; by allowing personal phone calls back to Russia (with limits); by providing the senior official with amenities commensurate with his position; by recognizing that Russians were generally frugal and would want to save their per diem however possible; and generally by identifying and effectively addressing human relations issues as they surfaced.

\section{Value to Both the U.S. and Russia}

On 27 March 1992, President George W.H. Bush approved the TOPAZ purchase at a meeting with Secretary of State James Baker and Secretary of Defense Richard Cheney, as the first Russian-U.S. government-to-government cooperative program in science and technology since the dissolution of the Soviet Union. ${ }^{9}$ As Al Marshall commented, "An enlightened foreign policy opened the door to the TOPAZ program, and the TOPAZ program encouraged good relations between the United States and Russia." TOPAZ preceded the Nunn-Lugar Cooperative Threat Reduction program (which provided assistance for dismantling or safely storing the weapons of the Soviet nuclear arsenal), although it was in its spirit, in that the TOPAZ program provided continued employment for certain former Soviet nuclear scientists, engineers, and technicians who might otherwise have been tempted by job offers from rogue states. What is important to remember is that the TOPAZ purchase was not intended as an assistance program; rather it allowed the United States to obtain advanced space nuclear power technology at a fraction of the cost of internal development. As Frank Thome commented, "The Russian TOPAZ design was unique to anything America had ever devised. This was done by using non-nuclear electrical heat for testing and qualification on Earth. The only thing we could say was, "Why hadn't we Americans thought of this?"' It is unlikely the United States will ever design a space reactor again without incorporating the Russian non-nuclear prelaunch testing design features that add safety and reduce risk.

The initial TOPAZ purchase was the model for a portion of the Nunn-Lugar Cooperative Threat Reduction program to counter the proliferation of weapons of mass de-

9 William J. Broad, "White House Drops Barrier to Buying Soviet Technology," New York Times (28 March 1992). 
struction known as the International Science and Technology Center (ISTC). The ISTC helped the newly independent Soviet republics by sponsoring research and development to utilize weapons technology for commercial purposes. However, after twenty years the Nunn-Lugar program and the ISTC were renegotiated following Russian complaints that the original agreements implied it was a recipient of aid rather than an equal partner. Russian analysts Vladimir Orlov and Alexander Cheban commented that, among other complaints, Nunn-Lugar had given the United States the opportunity to intrusively visit secret facilities, a humiliating practice that had to be allowed as the U.S. was financing improvements to their security. ${ }^{10}$

The United States and a skeptical Russia have been discussing for many years how they might benefit from cooperation in scientific research and development. ${ }^{11}$ From the year 2013 forward, only limited cooperation will continue in those areas that are deemed to be in the national interests of both Russia and the United States. The New York Times reported that the United States will continue to help Russia secure nuclear and radiological material, but will no longer participate in destroying old missiles, securing the transportation of nuclear warheads, or eliminating chemical weapons. Russia has promised to continue such activities, but on its own, and as a result some U.S. contractors will leave Russia. ${ }^{12}$

Many of the Russian scientists, engineers, and technicians involved with the TOPAZ program continue to pursue the development of space nuclear power together with the leading Russian scientific research institutes independently of the United States. ${ }^{13}$ They have a goal of building a TOPAZ-II type power module by 2018 for use in propulsion in space for missions to the Moon and Mars; as a power source for commercial applications of manufacturing in zero-gravity; and as a means of dealing with the danger of asteroids. ${ }^{14}$ Academician Ponomarev-Stepnoy noted, "An effective way of [developing] space nuclear power should be the organization of international programs, allowing the use of the highest achievements of the participating countries." If such cooperation can be seen as a true partnership benefiting all the countries involved, there is cause for optimism that the warm friendships fostered by the TOPAZ program could continue in this and other fields of scientific cooperation.

10 Vladimir Orlov and Alexander Cheban, "Life after Death: Will the Nunn-Lugar Program Give Way to New Partnership?" Russia in Global Affairs (April/June 2013); available at http://eng.globalaffairs.ru/number/Life-After-Death-16057.

11 Anton Khlopkov, "What Will a Nuclear Agreement with the United States Bring Russia?" Security Index 13:2 (2007): 69-86.

12 Jackie Calmes, "Obama Asks Russia to Join in Reducing Nuclear Arms," New York Times (19 June 2013); available at http://www.nytimes.com/2013/06/20/world/europe/obama-asksrussia-to-join-in-reducing-nuclear-arms.html.

13 Valery Yarygin, "Apophis Can Change Priorities: TOPAZ, Enisey and Space Nuclear Power Systems (NPS) of the Second Generation," Atominfo.ru (10 December 2007); available at http://www.atominfo.ru/en/news/e0225.htm.

14 Kucharkin, et al., Космическая ядерная энергетика [Space Nuclear Power], 199-201. 
In the twilight of the Cold War, the TOPAZ International Program represented a prominent example of international cooperation in the peaceful application of thermionic space nuclear technologies that were highly classified in the past. The TIP was highly cost-effective: with NEPSTP it came close to space flight testing of the TOPAZII system, though this did not happen due to the anti-nuclear stand of the Clinton Administration. The program served as a model for U.S.-Russian cooperation in other domains, and led to many discoveries and product developments involving materials science. While the TOPAZ-II has never been flown in space, it has flown to the United States and returned back to Russia, thus paving the way to international science and technology cooperation.

Appendix

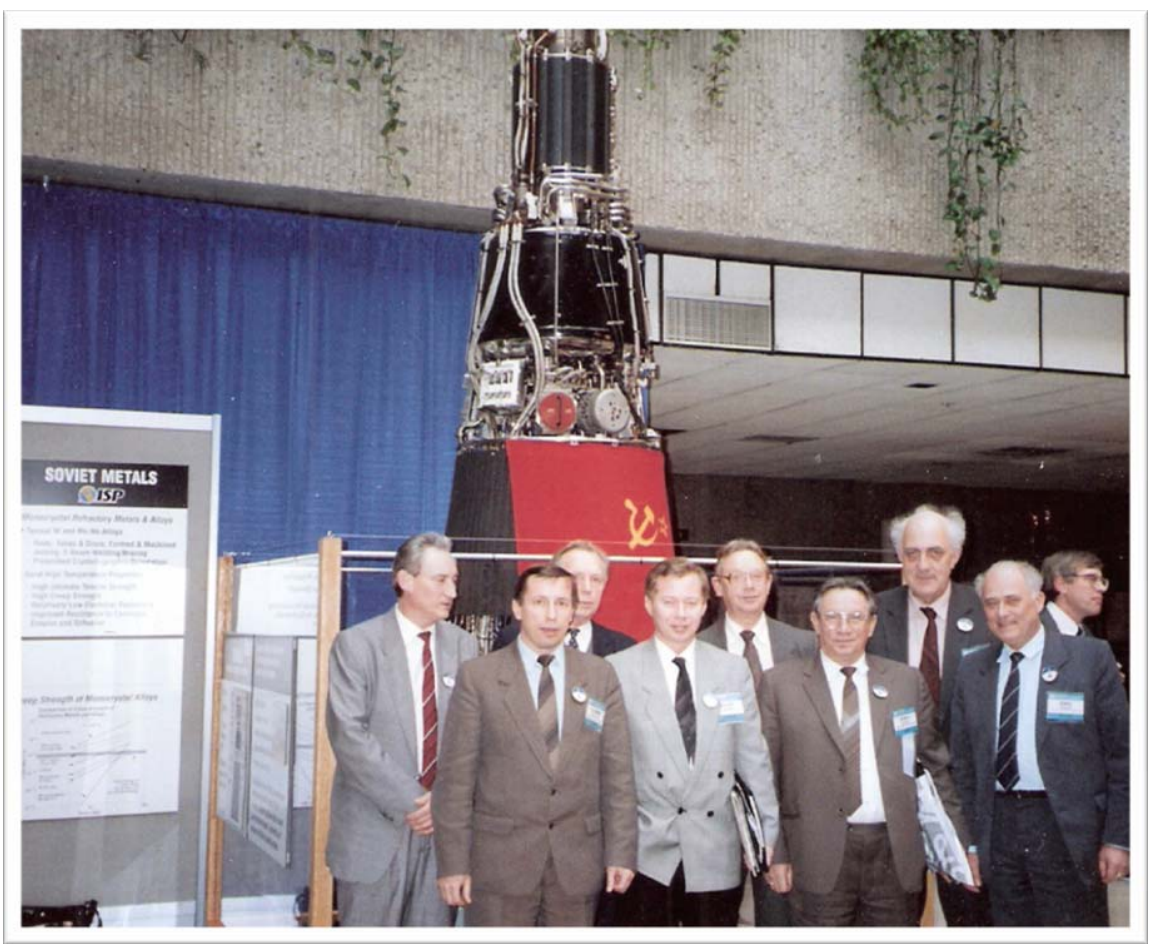

Figure 1: Soviet scientists led by Krasnaya Zvezda Director Georgiy Gryaznov (front center) with the TOPAZ-II display reactor at the New Mexico Space Nuclear Power Symposium, Albuquerque Convention Center, New Mexico, January 1991. 


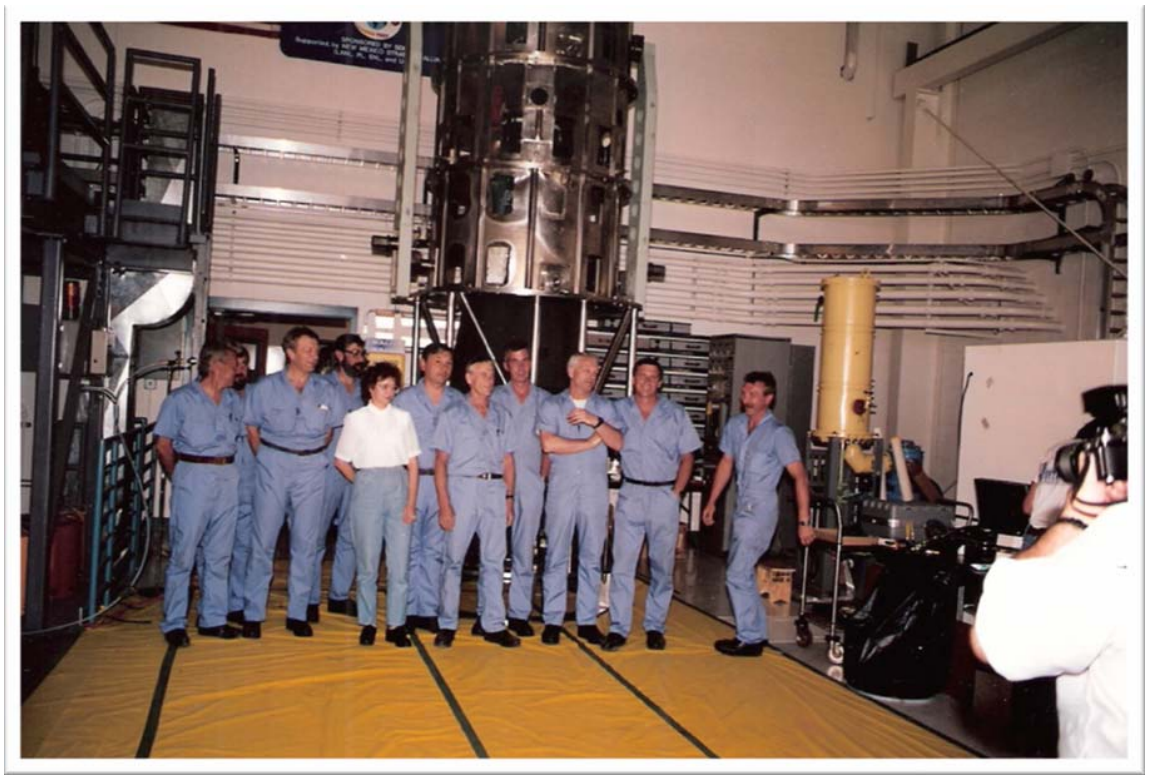

Figure 2: Russian technicians at the New Mexico Engineering Research Institute, University of New Mexico in Albuquerque, July 1992.

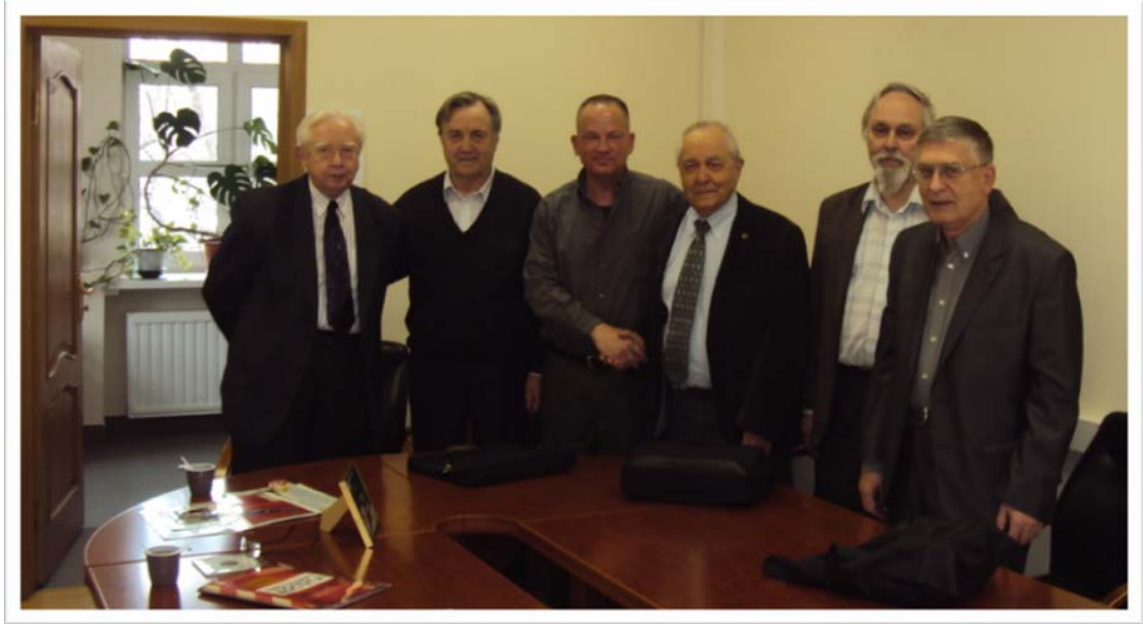

Figure 7: Academician N. N. Ponomarev-Stepnoy and Russian managers of the TOPAZII project with author, Kurchatov Institute, Moscow, Russia, April 2013. 


\section{Bibliography}

Broad, William J. "White House Drops Barrier to Buying Soviet Technology." New York Times (1992).

Calmes, Jackie. "Obama Asks Russia to Join in Reducing Nuclear Arms." New York Times (2013).

Fleck, John. "TOPAZ Research Funds at Risk." Albuquerque Journal (1996).

Khlopkov, Anton. "What Will a Nuclear Agreement with the United States Bring Russia?" Security Index 13, no. 2 (2007): 69-86.

Kucharkin, N. E., N. N. Ponomarev-Stepnoy, and V. A. Usov. Space Nuclear Power (Nuclear reactors with thermo-electric and thermionic conversion - "Romashka" and "Yenisey"). 2nd ed. Moscow: IzdAt, 2012.

Orlov, Vladimir, and Alexander Cheban. "Life after Death: Will the Nunn-Lugar Program Give Way to New Partnership?" Russia in Global Affairs (2013).

R. Smith, Jeffrey. "U.S. Won't Let Soviets Take Reactor Back Home; Conference Exhibit Trapped in Legal Limbo." Washington Post (1991).

Smolkin, Rachel. "TOPAZ Nuclear Program Called Failure; GAO Report Claims Mismanagement in Tech-Transfer Effort." Rocky Mountain News (1997).

Thermionics Quo Vadis? An Assessment of the DTRA's Advanced Thermionics Research and Development Program. Washington, D.C.: National Academies Press, 2001.

TOPAZ International Program: Lessons Learned in Technology Cooperation with Russia. Springfield, VA: Stephenson Printing, 1995.

TOPAZ International Program: Lessons Learned in Technology Cooperation with Russia. Springfield, VA: Stephenson Printing, 1995.

Yarygin, Valery. Apophis Can Change Priorities: TOPAZ, Enisey and Space Nuclear Power Systems (NPS) of the Second Generation. Atominfo.ru, 2007. 